\title{
The Study of Sales Promotion and Compulsive Buying
}

\author{
Mingming Wang $^{1} \&$ Xiaoting Jing ${ }^{1}$ \\ ${ }^{1}$ Shanghai University of Engineering Science, Shanghai, China \\ Correspondence: Mingming Wang, Shanghai University of Engineering Science, Shanghai, China. E-mail: \\ abao1228@126.com
}

Received: April 17, 2015

Accepted: May 13, 2015

Online Published: May 17, 2015

doi:10.5430/jms.v6n2p105

URL: http://dx.doi.org/10.5430/jms.v6n2p105

\begin{abstract}
Purpose - The purpose of this study is to explore the relationship between sales promotion and compulsive buying of clothing by using logistic regression measurement.

Methodology- Basing on theoretical and research perspectives, this study utilized observation and questionnaire. The final sample size was 162 subjects in both genders.

Findings- Logistic regression measurement indicated that the direct saving was the most effective promotion to stimulate compulsive buying. The stimulation of new and creative promotion method to compulsive was weak. The gift winning should be appealing and easy to get.

Research limitations- Some factors might affect triggering compulsive buying were not excluded.

Originality/value- The present study provided possible an approach to measure the logistic regression between sales promotion and compulsive buying.
\end{abstract}

Keywords: sales promotion, compulsive buying, model, logistic regression

\section{Introduction}

Since 1940s researches and studies has be conducted on the compulsive buying, a number of variables have been found to related to it including consumers' emotional requirements (Faber et al., 1995), personal characteristics (Yurchisin and Johnson, 2004). Kacen (2002) noted that with the development of modern marketing skills, more marketing methods have strongly stimulated compulsive buying. Ailawadi and Neslin found the promotions could make consumers to spend more and less hesitation.

In addition, researchers indicated that compulsive buying more often occur in fashion products such as clothing, jewelry, shoes and cosmetics (Christenson et al., 1994; McElroy et al., 1995; Yurchisin and Johnson, 2004; Johnson and Attmann (2009).

Despite the fact that many variables have been explored in previous compulsive buying studies. Variables are more focused on consumers rather than marketing tactics. The purpose of this study was to investigate the stimulation of sales promotion towards compulsive buying in the context of clothing, which is expected to have the contribution to fashion marketing.

\section{Theoretical Framework}

Mowen and Spears (1999) proposed a hierarchical approach to analyzing relationships between some variables and compulsive buying. A model composed cardinal, central and surface traits was founded. Based on Mowen and Spears' model, Johnson and Attmann (2009) conducted a study by making questionnaire research among 228 female college students to explore relationships between neuroticism, materialism and fashion interest. Using Amos 6.0, Johnson and Attmann assessed scales measurement properties. Result was as Figure 1: 


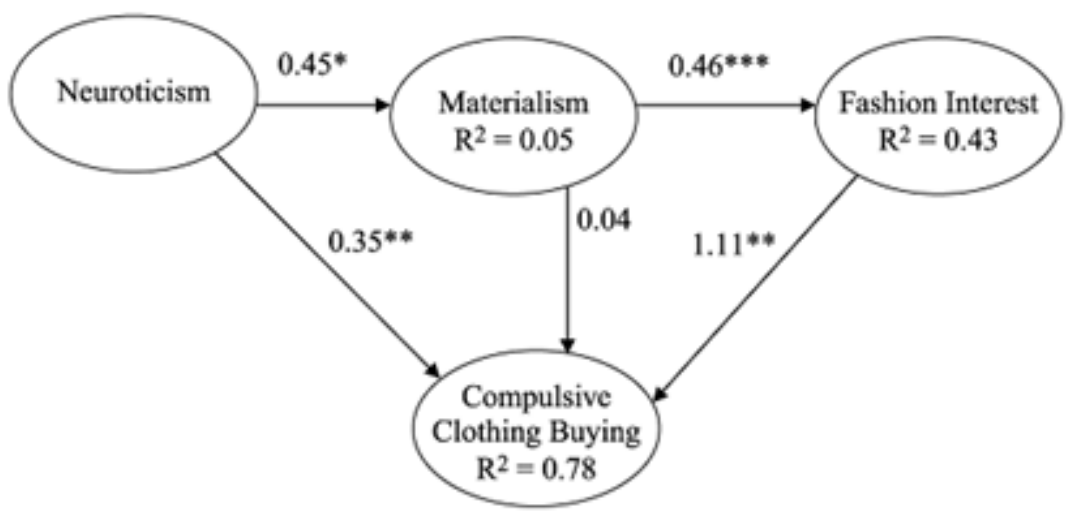

Note: ${ }^{*} p=0.05,{ }^{* *} p=0.01,{ }^{* * *} p=0.001$

Figure 1. Path coefficient of Johnson and Attmann (2009)

\section{Research Method}

The present study utilized Johnson and Attmann's model and data measurement method to exam the relationship between compulsive buying and five ways of sales promotions in context of clothing as variables. According to Zhang et al. (2006), sales promotion was divided into four categories: free, save, wins, and mix. One typical promotion method was chosen from each category, namely shopping more than 300 yuan get 50 yuan coupon in H\&M (H\&M), shopping more than 200 yuan get 80 yuan off in Honey (Honey), shopping more than 799 yuan win accessories in Lee (Lee), and 30\% off plus amour marketing in Who. a. u (Who. a. u).

Observation and questionnaire were combined. An observation sheet was designed to record consumers' buying behavior on the four promotion spots. When buying occurred, second questionnaire was followed to measure wherever the buying is compulsive buying. According to Rook (1987), and Doods (1991), compulsive buying was unplanned; therefore planned or unplanned buying was the main measurement of the compulsive buying. There were 200subjuects who participated in the present study. The final sample size was 162 subjects in both genders.

\section{Data Analysis}

Utilizing SPSS18.0, the logistic regression was measured. Measures were listed in the following tables.

Table 1. Measures for the promotion in H\&M

\begin{tabular}{lcccccccc}
\hline & & & & & & \multicolumn{2}{c}{$95 \%$ C.I } \\
H\&M & B & S.E. & Wald & P & OR & & \\
& & & & & & & Lower & Upper \\
& & & & & & & & \\
\hline Compulsive buying & 2.747 & 0.662 & 17.226 & 0.000 & 15.600 & 4.263 & 57.089 \\
\hline
\end{tabular}

Table 2. Measures for the promotion in Honey

\begin{tabular}{|c|c|c|c|c|c|c|c|}
\hline \multirow{2}{*}{ Honey } & \multirow{2}{*}{ B } & \multirow{2}{*}{ S.E. } & \multirow{2}{*}{ Wald } & \multirow{2}{*}{$\mathrm{P}$} & \multirow{2}{*}{ OR } & \multicolumn{2}{|c|}{$95 \%$ C.I } \\
\hline & & & & & & Lower & Upper \\
\hline Compulsive buying & 2.853 & 1.059 & 7.254 & 0.007 & 17.333 & 2.174 & 138.175 \\
\hline
\end{tabular}


Table 3. Measures for the promotion in Lee

\begin{tabular}{|c|c|c|c|c|c|c|c|}
\hline \multirow{2}{*}{ Lee } & \multirow{2}{*}{ B } & \multirow{2}{*}{ S.E. } & \multirow{2}{*}{ Wald } & \multirow{2}{*}{$\mathrm{P}$} & \multirow{2}{*}{ OR } & \multicolumn{2}{|c|}{ 95\% C.I } \\
\hline & & & & & & Lower & Upper \\
\hline Compulsive buying & 0.629 & 1.195 & 0.276 & 0.599 & 1.875 & 0.180 & 19.525 \\
\hline
\end{tabular}

Table 4. Measures for the promotion in Who. a. $\mathrm{u}$

\begin{tabular}{|c|c|c|c|c|c|c|c|}
\hline \multirow{2}{*}{ Who. a. u } & \multirow{2}{*}{ B } & \multirow{2}{*}{ S.E. } & \multirow{2}{*}{ Wald } & \multirow{2}{*}{$\mathrm{P}$} & \multirow{2}{*}{ OR } & \multicolumn{2}{|c|}{ 95\% C.I } \\
\hline & & & & & & Lower & Upper \\
\hline Compulsive buying & 0.405 & 0.986 & 0.169 & 0.681 & 1.500 & 0.217 & 10.361 \\
\hline
\end{tabular}

\section{Discussion}

Based on Johnson and Attmann's (2009) model, the present study developed a model which revealed the logistic regression of sales promotions related to compulsive buying.

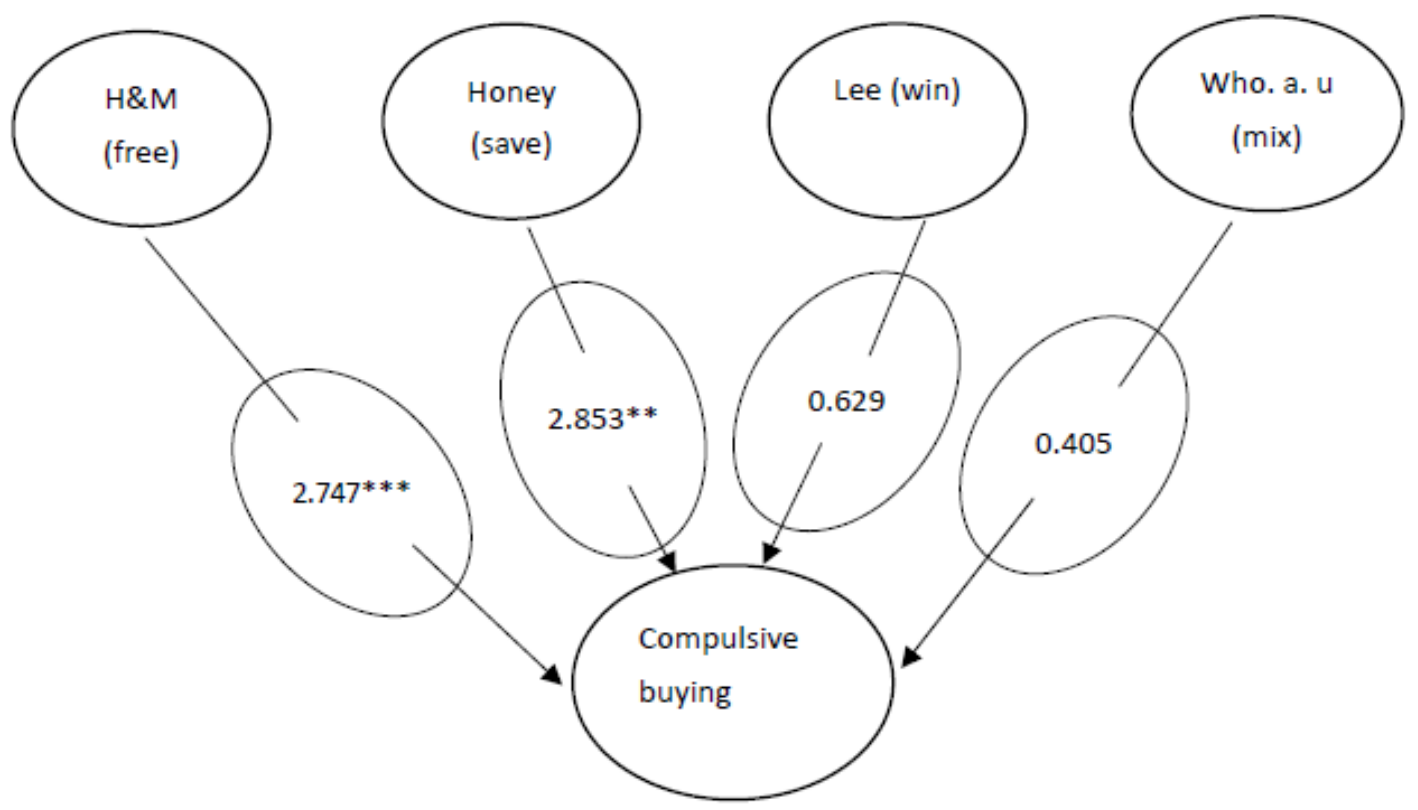

Note: $* \mathrm{p}=0.05, * * \mathrm{p}=0.01, * * * \mathrm{p}=0.001$

Figure 2. Logistic regression for the model

The present study indicated that promotions in Honey and H\&M had strong stimulation to compulsive buying, which belonged to free and save. The least favor one is the $30 \%$ off plus amour in Who. a. u. These results revealed that the direct saving was the most effective promotion to stimulate compulsive buying. The new and creative promotion method such as amour in Who. a. u might have contribution of pulling consumers into the store, while the relevance 
to compulsive was weak. The gift winning in Lee ranked in the middle, which suggested that gifts should be appealing and easy to get.

The present study explored the relationship between promotion and compulsive buying in the context of clothing. The limitation of the study was that only one promotion in each category was examined. In addition, factors might affect triggering compulsive buying such as brand preference, and extent of promotion were not excluded.

\section{References}

Bayley, G., \& Nancarrow, C. (1998). Impulsive purchasing: A qualitative exploration of the phenomenon. Qualitative Market Research, (2), 99-114. http://dx.doi.org/10.1108/13522759810214271

Beatty, S., \& Ferrell, M.E. (1998). Impulse buying modeling its precursors. Journal of Retailing, 74(4), 169-192. http://dx.doi.org/10.1016/S0022-4359(99)80092-X

Chandon, P., Wansink, B., \& Laurent, G. (2000). A benefit congruency framework of sales promotion effectiveness. Journal of Marketing, 64(4), 65-81. http://dx.doi.org/10.1509/jmkg.64.4.65.18071

Dodds, W.B., Monroe, K.B., \& Grewal, D. (1991). The Effects of Price Brand, and Store Information on buyers'product evaluations. Journal of Marketing Research, 28(3), 307-319. http://dx.doi.org/10.2307/3172866

Gilbert, D.C., \& Jackaria, N. (2002). The efficacy of sales promotions in UK supermarkets: A consumer view. International Journal of Retail \& Di stribution Management, 30(6/7), 315-322. http://dx.doi.org/10.1108/09590550210429522

Huff, L.C., \& Dana, L. (1998). An investigation of consumer response to sales promotions in developing markets: A three-country analysis. Journal of Advertising Research, 38(3), 47-56.

Johnson, T., \& Attmann, J. (2009). Compulsive buying in a product specific context: clothing. Journal of Fashion Marketing and Management, 13(3), 394-405. http://dx.doi.org/10.1108/13612020910974519

Kacen, J.J., \& Lee, J.A. (2002). The influence of culture on consumer impulsive buying behavior. Journal of Consumer Psychology, 12(2), 163-176. http://dx.doi.org/10.1207/S15327663JCP1202_08

Kollat, D.T., \& Willett, R.P. (1969). Customer impulse purchasing behavior. Journal of Marketing Research, 33(1), 79-83.

Mowen, J.C., \& Spears, N. (1999). Understanding compulsive buying and college students: a hierarchical approach. Journal of Consumer Psychology, 8(4), 407-430. http://dx.doi.org/10.1207/s15327663jcp0804_03

Rook, D.W. (1987). The Buying Impulse. Journal of Consumer Research, 12, 189-199. http://dx.doi.org/10.1086/209105

Rook, D.W., \& Fisher, R.J. (1995). Normative Influence on impulsive buying behavior. Journal of Consumer Research, 22(3), 305-313. http://dx.doi.org/10.1086/209452

Rook, D.W., \& Hoch, S.J. (1985). Consuming Impulses. Advances in Consumer Research, 12, 23-27.

Shi, Y.Z., Cheung, K.M., \& Prendergast, G. (2005). Behavioral response to sales promotion tools: A Hong Kong Study. International Journal of Advertising, 24(4), 467-486.

Utpal, M.D. (2000). Temptation and resistance: an integrated model of consumption impulse formation and $\begin{array}{lllll}\text { enactment. Psychology and } & \text { Marketing, } & \text { 17, }\end{array}$ http://dx.doi.org/10.1002/1520-6793(200011)17:11<955::AID-MAR3>3.0.CO;2-J 